\title{
Financing Roads through Tolls in Nigeria: The Role of Public-Private Partnerships
}

\author{
Dr. George Nwangwu \\ Research Fellow, African Procurement Law Unit, Department of Mercantile Law, Stellenbosch University and Honorary Senior \\ Research Associate in the Bartlett School of Construction and Project Management, University College London
}

\begin{abstract}
Nearly 18 years after the Government of Nigeria dismantled toll plazas along the country's highways, there is renewed interest by the present administration to re-introduce toll roads to help finance the construction, repairs and maintenance of the highways. This has been met with predictable opposition from different interest groups around the country. This paper notes that using tolls as a means of financing highways is not a particularly bad strategy, as there are several benefits that could accrue to the country from its use. However, the manner in which the proposed tolling appears to be structured will not resolve all the issues bedevilling the Nigerian road sector. For greater impact and sustainability, the financing of some of the major roads should be done in partnership with the private sector, through Public-Private Partnerships. This paper acknowledges the peculiar difficulties inherent in the use of tolls to finance roads in Nigeria and suggests policies that are required to make it successful.
\end{abstract}

\section{INTRODUCTION}

Road transportation is the principal means of moving goods and passengers in Nigeria, accounting for about 90 percent of all freight and passenger traffic within the country. ${ }^{1}$ However, despite the overwhelming reliance on this method of transportation, roads around the country are in a deplorable state. Nigeria has nearly $200,000 \mathrm{Km}$ of road network, majority of which is unpaved and a good part of the paved portions, in very poor condition. ${ }^{2}$ This is basically due to inability of successive governments to finance the construction of new roads and maintain the existing ones. Nigeria relies substantially on government budgets to fund the construction, maintenance, and rehabilitation of roads. This has proven to be substantially inadequate. According to the Africa Infrastructure Country Diagnostic (AICD) Report, benchmark and network stimulations reveal that an annual budget of around USD 240 million should ordinarily be earmarked for preventive maintenance in Nigeria. However, the Report shows that for most years, Nigeria had only

\footnotetext{
1 National Planning Commission, National Integrated Infrastructure Master Plan (NIIMP), pg.24

${ }^{2}$ NIIMP ibid Pg. 25

${ }^{3}$ Africa Infrastructure Country Diagnostic Report 'Nigeria's Infrastructure: A Continental Perspective' February 2011 Found online

at:

https://ppiaf.org/documents/3154/download

(last accessed on June 2, 2020)

${ }^{4}$ NIIMP supra Note1 Pg.121

${ }^{5}$ NIIMP Pg.26; See also the AICD Report Supra, Note 3. 2338
}

allocated about USD 50 million per year for road maintenance. $^{3}$ This is particularly low and the National Integrated Infrastructure Master Plan (NIIMP) estimates that the road sector will require an investment of about USD 350 billion over the next 30 years for rehabilitation, expansion and upgrading. ${ }^{4}$ There has also been a historical trend by the public sector towards prioritizing new road construction over the maintenance of existing roads. This has led to the further deterioration of existing road infrastructure. ${ }^{5}$

It is apparent that Nigeria does not have the money to sufficiently fund the construction and repair of its road network. The budgeted expenditure for road construction and maintenance has also continued to decline over the years, thus worsening the situation. For instance, the federal budget for road construction in 2018 was N138.8bn and N159.5bn for repairs. This figure declined in 2019, where N124bn was budgeted for road construction and N103.3bn for repairs. ${ }^{6}$ These figures are particularly low compared to what the

\footnotetext{
${ }^{6} 2018$ and 2019 Appropriations Acts. It is important to note two critical issues regarding these budgetary estimates: The first is that these figures earmarked for repairs are not entirely for preventive maintenance, as a substantial portion is usually dedicated to extensive rehabilitation of the roads. The second is that the budgeted figures are hardly ever good indications of the actual amount that was spent on particular sectors since the performance of the budget and actual amount released are typically lower than the budgeted figures due to government's overly optimistic revenue
} 
country requires. It is therefore imperative that the government explores alternative means of financing the construction and maintenance of roads within the country, otherwise the country will continue to miss out on the economic benefits that arise from enabling the movement of goods and people around the country. ${ }^{7}$

The problem with the road sector in Nigeria is not just one of lack of finance, there is also a lack of maintenance culture and inefficient governance systems within the public sector. For example, Nigeria has a Federal Roads Maintenance Agency (FERMA), which is funded through the budget, responsible for road maintenance and rehabilitation. ${ }^{8}$ However, FERMA has been very ineffective because of inadequate funding. Also, its governance structures and procurement procedures are overshadowed by public sector norms, which are very opaque in nature. This is clearly an impediment to the agency's efficiency, independence and accountability. ${ }^{9}$ The government therefore requires a revolving and consistent pot of money that is dedicated to road maintenance and managed in a way that ensures accountability and oversight.

It appears that Public-Private Partnership (PPP) is best suited for resolving the twin issues of lack of finance and inefficiency in the management of the country's road network. The suggestion for the use of PPPs as an alternative means for funding Nigeria's road sector is not novel. For instance, the NIIMP restates the intention of the country to adopt PPPs to help meet its obligations in the road sector. The reasons for suggesting the use of PPPs as a solution are obvious. PPPs have the advantage of attracting private sector finance and its bias towards whole life cycle costing encourages the long-term maintenance of assets. In furtherance of the recommendation of the NIIMP, the Federal Ministry of Works which is the agency in charge of road

projections. For instance, the 2019 budget only had a 58\% performance.

7 There is a connection between infrastructure and development. Infrastructure has an impact on poverty alleviation, equality, growth and other specific development outcomes such as job creation, market access, health and education. See Ruiz-Nunez F. and Wei Zichao, 'Infrastructure Investment Demands in Emerging Markets and Developing Economies' World Bank Policy Research Paper 7414, pg. 2. See also the National Infrastructure Master Plan that states that Nigeria's current infrastructure stock ranges between $20 \%$ to $25 \%$ of GDP, this is way below the international benchmark of about $70 \%$ of GDP.

${ }^{8}$ Created under the Federal Roads Maintenance Agency (Establishment, etc.) Act 2002. See also the subsequent amendment to that Act by the The Federal Roads Maintenance Agency (Amendment) Act No. 18, 2007.

${ }^{9}$ AICD supra

${ }^{10}$ Dan Agbase, 'Return of Toll Gates? First, Fix the Roads' The Guardian Newspaper found online at: 2339 construction and maintenance in the country, set up a PPP department to help prepare projects for delivery using PPPs. This initiative has been largely unsuccessful and to date, that department has not been able to reach financial close on any project. Given the prevailing poor state of the roads and continued lack of funding for road maintenance, it was therefore not surprising when the Minister of Works on Housing, Mr. Babatunde Raji Fashola, announced that toll roads will soon be reintroduced in the country.

Also, unsurprisingly, the decision to reintroduce toll roads have been met with a predictable level of opposition. The opposition political party, the People's Democratic Party (PDP), described the plan as insensitive, ill-conceived, and anti-people. PDP complained that it would lead to the increase in the price of goods and services. ${ }^{10}$ Other stakeholders, like the Nigerian Labour Congress, were of the opinion that the roads were in very bad condition and that the roads should first be fixed before any toll is charged for their use. ${ }^{11}$ There were also complaints about the proposed regional distribution of the toll plazas, even though there was no official indication of where the new toll plazas would be sited. $^{12}$

\section{WHY TOLL ROADS?}

The decision to re-introduce toll roads is however not illconceived and there is some merit in the decision. The use of road use charges is not unique to Nigeria as over the years the principle across the globe has been that road users should be taxed to ensure the availability of funds for the continued maintenance of the roads. Apart from physical toll plazas, different countries from around the world have adopted varied methods of collecting road user charges, including fuel taxes, ${ }^{13}$ vehicle licensing fees, ${ }^{14}$ vehicle distance travelled charges, ${ }^{15}$ vignettes ${ }^{16}$ and congestion charges. ${ }^{17}$ These

https://guardian.ng/opinion/return-of-the-toll-gates-firstfix-the-roads/ (last accessed on $22^{\text {nd }}$ April 2020); This Day Newspaper (online) 'The Return of Highway Tolls' https://www.thisdaylive.com/index.php/2019/10/06/thereturn-of-highway-tolls/ (last accessed on May $7^{\text {th }}, 2020$ )

11 Legit Newspaper 'Fix Bad Roads Before Returning Toll Gates on Highways- Labour Tells FG' https://www.legit.ng/1263793-fix-bad-roads-returning-tollgates-highways---labour-tells-fg.html (last accessed on May $\left.7^{\text {th }}, 2020\right)$

${ }^{12}$ Vanguard Newspaper 'Rep Rejects Toll Road in the South East' (online) https://www.vanguardngr.com/2019/10/reprejects-toll-gates-in-southeast/ (last accessed on May $7^{\text {th }}$ 2020)

${ }^{13}$ United Kingdom, Finland, Norway and France

${ }^{14}$ Norway

${ }^{15}$ Sweden, Finland and Norway

${ }^{16}$ Czech Republic and Hungary

17 United Kingdom 
charges are based on the realization by governments across the world that they require a dedicated pool or fund with which to continue to keep roads in good repair. The logic is simply based on the fact that timely maintenance of roads is less expensive than delayed maintenance. For instance, it is estimated that the cost for reconstruction of roads is five times as much per kilometre as an overlay and twenty-five times as much as bituminous surface dressing. ${ }^{18}$

One of the common misconceptions is that since the roads are already paid for through citizens' taxes, there is no reason why the citizens should be taxed again. In other words, that it would amount to double taxation to so do. However, roads like any piece of infrastructure require constant maintenance, otherwise it becomes more expensive to replace. It is also important to note that most of these roads were built with borrowed funds, which require repayment. Therefore, the government needs to raise money from the asset to meet its obligations to lenders. It is therefore more equitable to tax those who have used the roads, than to ask every citizen to contribute towards the repayment of the loans. For instance, the Federal Government of Nigeria recently financed the construction of some roads using Islamic bonds which must be repaid.

Tolling may also be used to achieve other government policies apart from raising finance for replacement, maintenance, and repair of roads. Tolls help provide security and a higher level of convenience, reliability, or safety. This is because tolls can serve as a sort of oasis where road users can get help to repair their vehicles, get some rest and refreshment. There is even the argument that some of the security challenges being experienced on the highways in Nigeria would be reduced if toll plazas manned by security personnel are mounted along the roads. Tolls have also been used to manage congestion by discouraging road users from using particular roads at certain times in the day to manage vehicular traffic around designated urban centres. Leasing out certain roads for tolling may also enable government raise immediate funds to finance other projects instead of approaching lenders. The money raised upfront in this way could be used for other social infrastructure like schools and hospitals.

\footnotetext{
${ }^{18}$ Querioz C. etal 'Mechanism for Financing Roads: A Review of International Best Practice' December 2016' InterAmerican Development Bank. Technical Note Number IDBTN-1102 pg.5

${ }^{19}$ Federal Ministry of National Planning, Fourth National Development Plan, 1981-1985, Federal Ministry of Planning, Lagos, Nigeria, 1981.
}

\section{HISTORICAL OVERVIEW OF TOLL ROAD PROJECTS IN NIGERIA}

The issue of using tolls to finance the federal highways did not surface in Nigeria's planning horizon until the $4^{\text {th }}$ National Development Plan, where it was noted that:

"Moderate road tolls will be imposed on selected bridges and highways of expressway standard as a means of raising additional revenue for more effective maintenance of existing facilities. In general, efforts will be made to relate road user charges to road investment/maintenance cost". 19

This plan ostensibly led to the subsequent construction and operation of tollgates along most of the Federal Highways. In the 1991 - 1993 National Rolling Plan, the issue of user charges was re-echoed in the policy guideline on the highway sector as:

"need to evolve effective cost recovery strategies such that user charges will be designed to equate maintenance costs as tolls will be extended to more roads and bridges to generate the funds for the provision of additional facilities". ${ }^{20}$

Subsequently, 31 toll plazas became operational across the Federal road network in Nigeria. The toll plazas were initially managed by a Toll Gate Committee within the then Federal Ministry of Works and Housing. ${ }^{21}$ The revenues generated were paid into the Consolidated Account of the Federal Government. Toll collection was later outsourced to private firms on the understanding that government's share of receipts from tolls would be remitted to the government and devoted to the maintenance of the highways. ${ }^{22}$ Payment was cash-based using a manual ticket system. However, it appeared that during the period that toll collection was outsourced, revenues generated were seldom remitted to government. The attempts by the Ministry of Works to revoke the outsourcing contracts led to lengthy court litigations. From complaints made by road users about the condition of the roads during the period that the tolls were in place, it appears that the primary justification for the tolls (road maintenance) was not achieved, while the secondary objective i.e. revenue generation was met only in part. ${ }^{23}$

In 2003, President Obasanjo ordered the removal of toll roads across the country to take effect from $1^{\text {st }}$ of January 2004 . The President proclaimed that the toll revenues would be replaced with proceeds from the Petroleum tax of $=\mathrm{N}=1.50 \mathrm{k}$ per litre of petroleum product sold. This new petroleum tax would be dedicated to improving federal roads around the country. The president explained that the reason for the change in policy

20 Federal Ministry of National Planning, National Rolling Plan 1991 - 1993 Vol. 1, Lagos, Federal Ministry of Planning and Budget: 124.

${ }^{21}$ Federal Ministry of Transport, Draft Federal Road Toll Policy

22 Federal Ministry of Transport, Draft Federal Road Toll Policy, ibid

${ }^{23}$ Federal Ministry of Transport, Draft Federal Road Toll Policy, ibid 
was that the entire 31 toll roads generated a paltry $=\mathrm{N}=63$ million daily, which was hardly sufficient for maintaining the roads. He also alluded to the fact that the toll gates constituted an inconvenience to motorists and encouraged corruption. ${ }^{24}$ In truth, corruption was the fundamental reason why the tollgates never worked and was also responsible for exacerbating most of the other challenges with the toll roads. The toll roads provided opportunities for different security agencies to converge and extort money from helpless motorists. ${ }^{25}$

Since the abolition of toll roads in 2004, no tolls have been collected on Nigerian federal highways. The reason for the failure of the country's first attempt at tolling was not necessarily because outsourcing was a bad strategy. It was simply due to the way the entire tolling process was structured. It turned out that the outsourcing of toll collection was not done through a competitive or transparent procurement process. The roads were simply awarded to influential people or retired military officers for political patronage. Another fundamental deficiency in the tolling experience of the federal roads was the channelling of toll receipts to the Federation account. This ensured that the Ministry of Works had no access to the collected funds to execute programmed maintenance of the tolled roads. Road maintenance was merely done through yearly budgetary appropriations.

During the period in which the tollgates were operational, there were also several legal and policy attempts to find sustainable means of making funds available for road maintenance. This was confirmation that the toll roads were just not providing sufficient funds for road maintenance. For instance, in 1999 the Presidential Policy Advisory Committee had recommended that the funding of highways across the country should be improved by establishing a road fund. It was recommended that the Road Fund should be funded from a number of sources including highway tolls, vehicle taxes, trucks weighbridges, parking fees and petroleum taxes. ${ }^{26}$ Nothing concrete materialised from the work of this Committee and these recommendations were never implemented.

\footnotetext{
${ }^{24}$ Nwannekanma B. etal 'Why Buhari Shouldn't Rebuild Toll Gates Obasanjo Removed' Guardian Newspaper found online https://guardian.ng/news/nigeria/national/whybuhari-shouldnt-rebuild-toll-gates-obasanjo-removed/ (last accessed on $7^{\text {th }}$ of May 2020)

25 Dele Bankoko found online http://nigeriavillagesquare.com/forum/threads/obasanjoabolishes-toll-gates-in-nigeria.792/ (Last accessed $7^{\text {th }}$ May, 2020)

${ }^{26}$ Central Bank of Nigeria 'Highway Maintenance in Nigeria: Lessons From Other Countries' Research Department Occasional Papers, No.27, April 2003.
}

${ }^{27}$ See the Petroleum (Special) Trust Fund Act, No.25 of 1994 2341
Prior to the establishment of the Presidential Policy Advisory Committee, the maintenance of federal highways was already mostly done by the Petroleum Trust Fund ( PTF). ${ }^{27}$ This was an agency that was set up under the Abacha regime to fund and execute projects across various sectors of the Nigerian economy. The PTF funded road projects through the allocation of part of the proceeds from the sale of petroleum products. Also in 2002, the Federal Roads Maintenance Agency (FERMA) Act was passed into Law. ${ }^{28}$ This Act created FERMA, with the primary responsibility for ensuring the effective maintenance of all existing federal roads. ${ }^{29}$ The funding for the activities of the agency was to be from amongst other sources, the annual subventions from the Federal Government as provided in the Appropriations Act, all monies collected from toll gates and monies accruing from road concessions..$^{30}$ It is not clear whether FERMA has earned any substantial revenue through the tolling of roads.

Since the abolition of toll roads by the then President Obasanjo, there have been attempts by different administrations within Nigeria to reintroduce tolling. In 2012, the Jonathan administration contemplated the re-introduction of toll roads. The then Minister of Works, Mr. Mike Onolememen had suggested that toll roads would be reintroduced and described the earlier decision of the Obasanjo administration to abolish tolling as a disservice to road maintenance. According to the Minister, by reintroducing toll roads "we should be able to sustain the allyear maintenance of the road... we seem to be the only country in the world where you don't have appropriate institutional framework to pull funds together and manage our roads." ${ }^{31}$ The Minister also undertook that only roads in good condition would be tolled. In 2014, Onolememen again reiterated the intention of the government to introduce tolling. However on this occasion, the Minister had somewhat refined the government's position to the effect that tolls would only be collected on roads constructed through PPPs. ${ }^{32}$ The Jonathan administration after carrying out a number of stakeholder engagements produced a draft Federal tolling policy. This policy was to lay the groundwork for the re-

\footnotetext{
${ }^{28}$ FERMA Act ibid

${ }^{29}$ S.7 FERMA Act

${ }^{30} \mathrm{~S} .14$ of FERMA Act
}

${ }^{31}$ Madukwe Bartholomew 'Minister Explains Reintroduction of Toll Gates' Found online at https://www.vanguardngr.com/2011/11/minister-explainsreintroduction-of-toll-gates/ (Last accessed on June 02, 2020)

32 Premium Times 'Toll Gates, Weighbridges to Return to Nigerian Roads- Minster Onolememen https://www.premiumtimesng.com/news/152968-tollgates-weigh-bridges-return-nigerian-roads-ministeronolememen.html 
introduction of tolling in the country. The drat tolling policy was not presented for Federal Executive Council (FEC) approval and therefore never operationalized.

In 2015 after the swearing in of the Buhari administration, the government had also considered the option of re-introducing tolling in Nigeria. On Friday, $10^{\text {th }}$ July, 2015, the "Committee for the Re - Introduction of Toll System in Management of Nigerian Roads" was formally inaugurated by the then Head of the Civil Service of the Federation (HOCSF), Mr. Danladi Kifasi, who reiterated the intention of the government to reintroduce tollgates as an effective tool for the management of Nigeria's road network. The Head of Service stressed that this decision was borne out of the fact that funding was a major constraint to road construction and maintenance. The need for the reintroduction of toll roads had therefore become imperative considering that the government lacked the capacity to maintain the country's large road network. He also alluded to the fact that toll roads were a more sustainable means of financing roads in Nigeria.

In 2019, the Minister of Works Mr. Babatunde Fashola restated the intention of the Buhari administration to reintroduce tolling. According to the Minister:

"We expect to return toll plazas. We have concluded the designs of what they will look like; what material they will be rebuilt with; what new considerations must go into them. What we are looking at now and trying to conclude is how the backend runs. And that is important because we want to limit significantly, if not totally, eliminate cash at the plazas while ensuring that electronic devices that are being used do not impede rapid movement... We are also now faced with the need to acquire more land to establish the width of the toll plazas because I believe we are looking at 10-lane plazas so that there can be more outlets. So, we need to acquire more land. That is the work that is currently being done now. "33

While the finer details of how the tolling will be financed or operated have however not been released, it appears that the Minister intends to operate the toll plazas directly using public servants. There are doubts whether this type of arrangement will work, as it did not work previously. The Nigerian public sector is notoriously inefficient and suffers from serious perceptions of being corrupt. For instance, the toll plazas currently being operated by the Federal Airport Authority of Nigeria (FAAN), using their staff, across several

\footnotetext{
33 This Day Newspaper Online 'The Return of Highway Tolls' October 6, 2019. Found online at https://www.thisdaylive.com/index.php/2019/10/06/thereturn-of-highway-tolls/ (Last accessed on $16^{\text {th }}$ of April, 2020)

${ }^{34}$ Commonly known as Executive Order No.007 of 2019.

35 'Companies, Roads to be Constructed Under Buhari,s Executive Order 7' Found online at
}

airports in Nigeria are not properly run. One of the major reasons why the country embraced privatisation and much later PPPs for the management of public enterprises is the realisation that the public sector is not best suited for business. PPPs also provide government with the broader policy option of being able to raise private sector finance and tap into private sector expertise. It is also a fact that the method of tolling being proposed by the Minister will not be far reaching enough to resolve the financing issues bedevilling the country's road sector. While some funds will be raised, it will not be sufficient to repair and replace most of the roads.

The Buhari administration has tried to embrace some form of PPP for the financing of Federal roads. On $25^{\text {th }}$ of January, 2019 the Federal government issued the Companies Income Tax (Road Infrastructure Development and Refurbishment Investment Tax Credit Scheme Order) 2019. ${ }^{34}$ This order was made pursuant to the executive powers granted to the president under the constitution. Under this executive order, private companies would be able to finance the construction or refurbishment of federal roads. The investors would be able to recoup their investment by utilising the approved total costs expended on eligible roads as a credit against their annual income tax. The scheme has a duration of 10 years. Since the Executive Order has been signed, it has been reported that 6 companies have applied to construct 19 roads totalling about $794.4 \mathrm{~km} .{ }^{35}$

\section{What are PPPs?}

PPPs may be defined as long term relationships between public sector agencies and private sector entities under which the responsibility for any or all of the combination of designing, financing, construction, management and operation of public infrastructure and utilities that were traditionally undertaken by the public sector are contractually shared and jointly undertaken by both the public and private sector, usually in proportion to the kind of risks each party can best carry. ${ }^{36}$ Over the years, PPPs have become very popular for the delivery of infrastructure projects in Nigeria. As government funds continue to diminish and the need for infrastructure increase, the government of Nigeria like most governments across the world, has basically turned to PPP for the delivery of power assets, airports and seaports amongst others. However, there have been very few projects in the road sector.

https://insidebusiness.ng/65602/full-list-companies-roadsto-be-constructed-under-buharis-executive-order-7/ (Last accessed on June 2,2020) .

${ }^{36}$ G. Nwangwu 'The Legal Framework for Public-Private Partnerships (PPPs) In Nigeria: Untangling the Complex Web', European Procurement and Public Private Partnership Law Review, Volume 7 (2012), Issue 4, Pg. 268-277 
The advantage in the use of PPPs does not lie only in the fact that it helps governments attract private sector funds. PPPs also promote an efficient procurement regime, that ensures that only the best partners are given the opportunity to develop and operate infrastructure. ${ }^{37}$ The Bureau of Public Enterprises and lately the Infrastructure Concession Regulatory Commission (ICRC) have a history of carrying out very reliable procurement processes. The rigorous analysis and market testing which PPPs undergo ensure reduced whole life cycle costing and promotes value for money. For these reasons, PPPs ensure that only projects that are economically and commercially viable are pursued. PPPs if done properly also leads to more efficient operations and maintenance of infrastructure. The private sector party has a better incentive to design and build very sustainable and resilient infrastructure since it will typically also be charged with the responsibility for maintaining the infrastructure for many years.

Despite the many advantage that are likely to accrue from PPPs, it important to reiterate that PPPs are however not a silver bullet for resolving all the country's road infrastructure needs. There are projects that are just not viable through PPPs and government would therefore need to continue financing the construction of those types of roads. These will mostly be projects without sufficient commercial and economic returns to justify private sector investment. However, PPPs remain a viable addition to the options open to government for financing infrastructure. There remain ample local and international sources of funds for the financing of projects through PPPs. For instance, Nigeria has not been able to use its growing pensions asset to finance infrastructure. There is a great need for government to create the necessary environment to attract the growing pension assets, estimated to be about $=\mathrm{N}=9.81$ trillion as at October, 2019. ${ }^{38}$ The challenge of course is how to deploy these assets for infrastructure finance without risking their impairment. Also, the Sovereign wealth funds across the world are usually looking for where to invest and Nigeria's highways may be an attractive investment option if properly positioned.

PPP is no longer a new concept in Nigeria as it has been part of the infrastructure policies of successive governments, at least since the passage of the Infrastructure Concession Regulatory Commission (ICRC) Act in 2005. However, despite the promotion of PPPs as a major government policy,

\footnotetext{
${ }^{37}$ See the Infrastructure Concession Regulatory Commission, National PPP Policy on Public Private Partnership (PPP), The Presidency, Nigeria.

${ }^{38}$ Naira Metrics, 'Pension Fund Assets hits N9.3 trillion as investment in FGN Securities drops' Found online at: https://nairametrics.com/2019/08/10/pension-fund-assetshits-n9-3-trillion-as-investment-in-fgn-securities-drops/
}

(last accessed on June 2, 2020) there have been very few PPP projects delivered over the years. There have been several reasons adduced for the low utilization of PPPs in Nigeria, most of which relate to the financing structure of PPP projects. For instance, it has been suggested that PPPs have tended to be more expensive than traditional procurement solutions due to the high cost of borrowing available to the private sector, exorbitant transaction fees, high administrative charges for managing PPP transactions and over reliance on guarantees by private sector, thereby increasing government's contingent liabilities significantly. ${ }^{39}$ All these notwithstanding, the major reason for the limited use of PPPs for the financing of infrastructure in Nigeria is political. PPPs take a long time to prepare and deliver and government officials simply lack the patience. Elections arrive in 4-year cycles and politicians structure projects to fall within these cycles, to facilitate their reelections. Therefore, projects that extend beyond these cycles are usually not granted priority.

There are also institutional limiting factors on the use of PPPs. For example, there is very limited capacity within the Ministries, Departments and Agencies (MDAs) of Government to deliver PPP projects. Where these capacities are developed, the trained staff are not allowed to remain within PPP units in the ministries to work on projects or facilitate internal skill transfer. The idea of rotating staff within ministries is very common and should be the prerogative of the public sector administrators. However, there should be a way of moderating these types of rotations. At the minimum, MDAs should constantly have in-house staff with requisite skills in financial, legal, technical, procurement and project management areas. Where necessary the existing capacities should be complemented with external consultants to fill gaps. It is on record that the most effective method of knowledge transfer is through on-job learning. Therefore, as the public sector hire external consultants to advise government, they must ensure that these contractors are engaged in a manner that ensures the eventual knowledge transfer to public sector staff.

One major hindrance to the financing of PPP projects has been that majority of them have not been able to secure financing. This has been attributed primarily to the projects not being "bankable". This is primarily due to poorly prepared feasibility studies and lack of proper risk allocation and management. ${ }^{40}$ This denies projects long-term debts and

\author{
39 See for example: Hall, D. (2008) Public-Private \\ Partnerships (PPPs) Summary Paper, A Report \\ Commissioned by the European Federation of Public \\ Service Unions (EPSU). Pg 6. \\ 40 See Nwangwu George, Public Private Partnerships in \\ Nigeria: Managing Risks and Identifying Opportunities, \\ Palgrave Macmillan UK. 2016 Pg. 144
}


concessionary loans. In some instances, private sector parties have relied on overly optimistic revenue assumptions, with dire consequences for the affected projects. The further challenge for the government with this is that even where such projects progress with guarantees, government's contingent liabilities increases and eventually crystalizes with devastating consequences. Badly prepared projects are more rampant where guarantees are issued indiscriminately to private sector parties. This unwittingly transfers project risks back to the government and reduces the incentive for the private sector to carry out rigorous project analysis.

PPPs in the road sector have been very popular across the world. There have been several road sector PPPs in Latin America and even in other countries across Africa. ${ }^{41}$ The reason for the lack of interests in toll roads in Nigeria is a curious one and may be traced to historical antecedents, where its use have not produced the desired results. ${ }^{42}$ However, it is the position of this paper that the lessons learned from the experiences of the past may be used as a basis for reforming the use of toll roads in the country. This is against the backdrop that tolling appears to be one of the only few viable options open to government for financing road projects in the face of shrinking oil revenues and mounting national debts.

\section{PPP Options Open to Government for Financing toll roads}

There are several contractual options open to the government if it chooses to collaborate with the private sector in the financing of the country's road infrastructure. This will include:

\section{Management Contracts}

Under this arrangement, the private sector party manages an existing toll road on behalf of the government. In a management contract arrangement, the government typically assumes construction risk and traffic risk while the private sector party shoulders the operations and maintenance risk. Since upfront financing cost is borne by the government, the private sector investment in the project is limited. The government will normally pay the private sector in accordance with services rendered. The contract period is usually for a short period of time since the private sector does not need to recover any capital expenditure. Governments will use management contracts where the objective is to have a degree of flexibility over the management of its road network. Even though the private sector participates in the operation of public highways under a management contract, there is a general tendency not to classify it is a PPP. This is

\footnotetext{
${ }^{41}$ For example, the Dakar- Diamniado Toll Road in Senegal; Kampala- Entebbe Expressway, Uganda and National Road No. 6, Mozambique
}

due to insufficient risk transfer occasioned particularly by the limited financing provided by the private sector party.

This type of contractual arrangement can be utilized in the operations and maintenance of some of the country's existing highways instead of reverting to public sector operation, that appears to be contemplated by the Minister.

\section{$\underline{\text { Leases }}$}

Under this type of arrangement, the public sector grants a lease of a portion of a highway asset to the private sector. As consideration for the private sector paying periodic lease fees, the private sector party can collect tolls from the user public. Just like under a management contract, the responsibility of the private sector would relate to the operations and maintenance of the highway. However, the level of risk undertaken by the private sector party, particularly the financing risk, is much higher under a lease arrangement. In most cases, where the lease fee is fixed and payable upfront, the private sector party also assumes traffic risk. . Thus, where the user fee collected is less than projected, the private sector lessee bears the risk. A lease arrangement is suitable where the government wishes to recover upfront part of the construction cost of the highway for reinvestment into other projects. This unlocked value would otherwise have been lost under government's continued operation.

\section{Build Operate Transfer (BOT), Design, Build, Finance and Operate (DBFO) and Similar PPP Structures}

The management contracts and lease arrangements discussed above are more suitable for brownfield transactions, whereas these other PPP arrangements are more suited for greenfield arrangements. Therefore, where there is a need to transfer a greater amount of risk to the private sector investor, it is always better to use full PPP structures like Build Operate Transfer (BOT); Design, Build, Finance and Operate (DBFO) and Build Lease Operate Transfer (BLOT) and other similar structures. Under these models, the private sector party is responsible for raising all or a substantial portion of the financing for the project. The private sector is also responsible for the construction (and sometimes the design) of the highway project. The private sector party also has the responsibility for operating and maintaining the highway asset for an agreed timeframe before handing back to the government. The key to the success of PPP arrangements is the management of demand risk.

Demand or revenue risk is basically the risk that the project might not be able to attract sufficient traffic or that passengers will be unable to pay the type of tariff that is required to make

42 There is also the problem of the general resistance of citizens to additional tax. The argument is that the tax revenues from citizens have historically never been properly utilized by the government. 
the project viable or that there are competing roads or other infrastructure that make the revenue accruing to the project unviable. There are two main contract types for allocating demand risk in road sector PPPs. These are availability or annuity contracts and user charge or concession contracts. ${ }^{43}$ Under availability contracts, the government undertakes to make periodic payments to the private sector service provider regardless of whether road users utilize the road or not. The private sectors' remuneration is in this case is directly related to the quality and quantity of services it provides. In this case, the government is basically making annuity payments to the private sector party to cover the cost of constructing and managing the road, plus any agreed returns. Conversely, in user charge or concession contracts, the private sector provider collects tolls directly from the user public and bears the risk that the project may not recover enough revenues to pay for itself. It is important to note that there are also mixed forms of both types of contracts. For instance, the private sector party may collect tolls on behalf of government under an availability payment contract or agree to the use of shadow tolls as a measure of its revenues. Under shadow tolls, despite the fact that users do not pay toll fees, the demand risk is still shouldered by the private sector concessionaire since the amount paid to it by the government is dependent on the frequency of use of the facility.

Since the private sector party bears revenue risk under concession contracts, the private sector party will try to manage demand risk by first carrying out traffic studies to ensure that the volume of traffic on the road is adequate to earn sufficient revenues to fund the project and guarantee adequate returns. The private sector project proponent will also carry out "willingness to pay" surveys to ensure that the potential users of the toll road are willing and able to pay whatever amount that will ensure the commercial viability of the project. It is only where these studies are positive that the private sector can raise financing for the project. Over the years there have been serious questions about the accuracy and reliability of these studies and therefore financiers have

\footnotetext{
${ }^{43}$ lossa and Martimot identifies three payment mechanisms in PPPs, these are user charges, usage payments and availability payments. The usage payments are technically variants of the user charge and availability payments. See lossa, E. and Martimort, D. [2008], 'The Simple MicroEconomics of Public-Private Partnerships', Working Paper, (online)
}

http://papers.ssrn.com/paper.taf?abstract id=1318267

[last accessed on May 15, 2019]

44 Once the private sector investor has built the asset, theoretically the investor is now at the mercy of government adverse actions that can affect its commercial rights. This aspect of the relationship is dealt extensively in transaction cost economics and incomplete contract theory. See for example Oliver Hart 'Incomplete Contracts and Public mostly relied on revenue guarantee instruments to manage demand risk. This issue is further discussed in subsequent sections of this paper.

The positive results of the studies is not enough to guarantee the success of the project as the private sector is also compelled to defend its revenues from other potential adverse actions from the government that may threaten its revenues from the project. ${ }^{44}$ For instance the likelihood of the government building an alternative road in close proximity to a private sector operated tolled road, thereby effectively competing with the tolled road is a risk that the private sector party must anticipate and deal with. In some instances, an alternative means of transport might even compete with a tolled road making the road less viable. The use of "noncompete", "demand guarantee" and "compensation events" clauses have been used to deal with these sorts of risks. ${ }^{45}$ These types of clauses have also been criticized as making the government the insurer and guarantor of the earnings of the private sector and destroying competition and consumer choice. ${ }^{46}$ It has also been contended that the extensive use of these clauses may also have the overwhelming effect of stunting economic growth in the country. These fears manifest for instance where a non-compete clause forbids the government from the building a competing tollfree road near the location of the private sector operated toll road. ${ }^{47}$

\section{CASE STUDIES OF TOLL ROAD PROJECTS IN NIGERIA}

This section of the paper considers two road sector PPPs that have been carried out in Nigeria and analyses why they failed. This post-mortem will help in designing better toll road projects in Nigeria.

\section{LEKKI TOLL ROAD CONCESSION}

The Lekki toll road project was awarded to the Lekki Concession Company (LCC), a Special Purpose Vehicle (SPV) set up by an indigenous finance company, Asset Resource Managers (ARM) with Macquarie Bank of

Ownership: Remarks, and an Application to Public-Private Partnerships' The Economic Journal, Volume 113, Issue 486, March 2003.

45 This clause was utilized in the MMA2 Airport Concession project and forms the basis of the legal dispute between the parties. It was also one of the issues with the Lekki toll road project.

46 Dannin, E. 'Crumbling infrastructure, Crumbling Democracy: Infrastructure Privatization Contracts and Their Effects on State and Local Governance', (2011) 6 North western Journal of Law \& Social Policy Pg.47

47 There are likely scenarios where the clause limits government from intervening to provide desperately required infrastructure because of the penalties that may arise from the breach of these provisions. 
Australia and Old Mutual of South Africa as shareholders. The project was consummated under the now repealed Lagos State Roads, Bridges and Highway Infrastructure (Private Sector Participation) Development Act 2004, at a total project cost of USD $\$ 340 \mathrm{~m} .^{48}$

The project was a 30-year Build Operate and Transfer (BOT) project for the upgrade, expansion and maintenance of approximately $49.4 \mathrm{~km}$ of the Lekki Epe Expressway (Phase 1) and the construction of the $20 \mathrm{~km}$ of Coastal Road (phase 2). It was proposed that the new road would eliminate traffic congestion around the Lekki area, ensure for shorter journey times and better law enforcement around the project area. The project was financed using long-term debt and equity and the project cost was to be recovered principally through user tolls. The project was enabled by the provision of a $\$ 6.5$ billion abridged works guarantee and $\$ 5$ billion mezzanine loan to LCC pledged by the Lagos State Government. Also, the State Government waived all state taxes, charges, stamp duties and consent fees under the Land Use Act. The Federal Government also weighed in with a sovereign guarantee via a Federal Support Agreement to ensure the bankability of the project.

LCC had completed only a $4 \mathrm{~km}$ stretch of road from the Law school end of Ozumba Mbadiwe to the Maruwa bus stop when it set up a toll facility at the Admiralty road end. However, the company was unable to collect any tolls even after assurances that the tolls was for only the completed portion of the road. Instead, there were multiple protests by the residents. Two weeks after its initial announcement of the commencement of the operation of the toll facility, the Lagos State Government announced the indefinite suspension of collection of toll on the road. ${ }^{49}$ Several splinter stakeholder groups $^{50}$ emerged either threatening to sue the government or actually commencing legal proceedings against the government and the concessionaire. ${ }^{51}$ Some of the

48 This law was repealed by the Lagos State Roads (private Sector Participation) Authority Law 2007 which in turn has recently been repealed by the Lagos State Public Private Partnership Law 2011.

49 The Director General of the Lagos State Pubic -Private Partnership Office, Mr. Ayo Gbeleyi said that the suspension was to enable the State Government engage with the Concessionaire and other stakeholders

50 Stake Holder Forum (comprising indigenes, businesses, and residents of the Lekki Ajah axis of Lagos State and the Etiosa Heritage Group.

${ }^{51}$ For example, a Lagos based lawyer and resident of the area, Ebun Olu Adegboruwa went to court alleging fraud and challenging the government's right to toll the road as he considered the toll an infringement of his constitutional right to free movement. He also insisted that the Government should make available provisions of the contract for everyone to see and read. See Benson D. 'Lekki/Epe stakeholder groups asked the government to terminate the contract and pay the concessionaire off.

On 18 December 2011, the State Government reverted to the collection of tolls on the road. The government had been placed under considerable fiscal burden by having to pay shadow tolls to the concessionaire over the period. It was suggested by Governor Raji Fashola that the state had spent over 4billion, which could have been used in other developmental projects, on shadow tolls. ${ }^{52}$ The decision to resume the tolling of road again led to a massive protest by the residents of the area. ${ }^{53}$ At the end of the protest, a number of people were severely injured and 23 people were arrested including a governorship candidate of the opposition party. ${ }^{54}$ This led to one of the opposition parties in the state, the People's Democratic Party (PDP), to call for the impeachment of the governor if the governor continued with the collection of tolls on the road. ${ }^{55}$ The project was finally cancelled and the private sector investors paid off. The government continues to manage the tolling of the road directly.

One of the reasons why this project failed was because of the lack of stakeholder engagement and communication. Stakeholder opposition is one of the principal reasons why many toll road projects fail. Road users ought to be sensitized about the reason for tolling the road and how the toll rates were arrived at. Consultation with stakeholders does not stop after toll collection commences on the road but continues throughout the lifespan of the private sector concession. Another problem with the project was that the tolls charged on the road were structured to escalate with inflation. At some point the project became too expensive for the government who were unwilling to transfer the cost to citizens. It therefore appears that proper affordability studies were not carried out prior to the concession of the road as a PPP. If proper feasibility studies were done and therefore proper willingness

Expressway Toll Plaza: Lagos Govt Violated our Fundamental Right to Protest - Adegboruwa' Vanguard Newspaper $22^{\text {nd }}$ December 2011 pg.8

52 This assertion was made by the Governor whilst presenting the 2012 budget. See This Day Newspaper of December 11, 2012.

53 Tagged "Occupy Lekki" See Sahara Reporters 'Occupy Lekki: Lagos Protests Against Lekki Toll Gate' (online) Available at: http//www.saharareporters.com/newspage/occupy-lekki-lagos-protests-against-lekki-toll-gate (last accessed August 12, 2013)

${ }^{54}$ Okoruwa S. and Olabulo O. '1 Killed, Many injured in Lekki Tollgate Protests' Nigerian Tribune Newspaper, May 28, 2019 Pg. 4

${ }^{55}$ Compas Newspaper 'PDP Calls for Fashola's Impeachment Over Lekki Toll Plaza Nigeria Compass Newspaper, December 16, 2011 pg. 12 
to pay surveys carried out, it would have become obvious that road users might not be able to pay the proposed tolls. This is because while the tolls escalated with inflation, salaries of the toll users did not and therefore it made no sense to escalate toll fees based on inflation.

\section{Lagos-Ibadan concession}

The 110km Lagos - Ibadan dual carriageway was built around the period of Nigeria's $3^{\text {rd }}$ National Development Plan at an initial cost of N90m and inaugurated in August, 1978. ${ }^{56}$ It was one of the expressways formerly tolled by the Federal Government to recoup its maintenance cost. The road is one of the busiest in the country given its link to seaports in the commercial centre of Lagos and to both the Eastern and Northern parts of the country.

In April 2009 the road was concessioned to Bi-Courtney Highway Services, for 25 years and valued at N90billion. ${ }^{57}$ This was the first federal road to be concessioned to a private entity under a PPP arrangement. Preparatory work, prior to the signing of the concession, took 27 months, however there was no evidence that the concessionaire emerged through a competitive bid process. The scope of work included the full reconstruction of the existing carriageways from Lagos to Ibadan; the provision of two additional lanes in each direction of travel between Lagos and Sagamu interchange, thus making it four lanes in each direction of travel. There were also provisions for associated facilities for the safety, security, welfare of road users and free flow of traffic. ${ }^{58}$ Upon completion, Bi-Courtney was to operate and maintain the road to a predetermined level of service. The company was expected to recoup its investment through the collection of tolls and other charges on road support services such as trailer parks and rest areas.

The project never actually reached financial close. The concession granted to Bi-Courtney was revoked in November 2012. The Minister for Works, Mike Onolememen announced that the road was revoked due to breach of contractual terms, particularly the failure of the concessionaire to secure funds for the project. An EPC contract was subsequently awarded to two construction firms RCC and Julius Berger to complete the project. The concessionaire on its part alleged that the government was responsible for the failure of the project and sued the government for breach of contract.

This project failed due to a poorly conducted procurement process or essentially a lack of it. There is no evidence that the project was awarded through a competitive bid process as the concessionaire was suddenly announced by the government. A rigorous competitive bid process would have thrown up several viable private sector concessionaire options for the government. It would also have led to the emergence of several consortiums, having partners with diverse competencies bidding for the project. In this case, the project was simply awarded to single project developer with limited experience in PPPs. It was therefore not particularly surprising that the concessionaire failed to raise money to commence the project three years after its award.

\section{Issues to consider when setting up PPP toll roads:}

From the case studies above, it is obvious that there is nothing wrong with the idea of toll road PPPs, but rather the manner in which the projects have been designed, prepared and procured in Nigeria, so far. Examples from different toll road projects across the world show that certain factors ought to be taken into consideration when considering road sector PPPs. This section looks at these issues in detail.

\section{PROJECT SELECTION}

Proper project prioritization and needs analysis should be carried out before commencing a toll project. This is important so that only projects that are likely to offer the most economic and social rewards are given priority. Roads that are selected for tolling must be viable. In cases where toll fees alone will be insufficient to payback the cost of the project, an affordability analysis ought to be conducted to ensure that government can afford whatever support is required to make the project viable. As part of the project preparation phase, a business case should be prepared for every potential toll project. This document should be robust enough to provide decision makers with sufficient information to make the right decisions.

In many cases in Nigeria, it may well be that toll revenues would be insufficient to ensure that the private sector investor is able to recover its investment and that toll revenues will supplement budgetary allocations. In such cases, and where the government insists on proceeding with the project as a PPP, the government must clearly justify why it intends to proceed with the project despite the potential subsidies that will be provided through the budget. In some cases, the decision to proceed as a PPP might be justified due to a value for money (VFM) assessment confirming that the lifecycle cost for the PPP project is lower than if the government funds the project through traditional procurement. This might be the case where for instance, the long-term maintenance cost of the toll road is factored into the entire project cost. All these factors need to be taken into consideration in making the decision whether to finance the construction of a project through PPPs or otherwise.

\section{TRAFFIC RISK}

As stated in the previous sections of this paper, one of the most important factor in the determining the economic and financial viability of toll roads is the volume of traffic and the 
willingness of the road users to pay commercially viable tolls to use the road. To achieve this, project proponents need to have robust traffic forecasts. However, the problem with traffic forecasts is that is based on assumptions which are susceptible to change from time to time. For instance, predicting future traffic growth is very difficult as it is based on unpredictable factors like future economic growth. It is indeed a lot easier to generate traffic forecasts when the project is brownfield as some of the assumptions are then based on existing data. Greenfield projects are more problematic since it is based on predictive models.

It is therefore not surprising that one of the most common factors leading to the failure of toll road PPP projects is the mismanagement of traffic risks. This is basically the risk of actual traffic being lower than the forecasted numbers. Empirical evidence shows that traffic risk is very significant in toll roads. Several of these studies show that the inaccuracies between projected and actual traffic volumes or revenues is often very large. ${ }^{59} \mathrm{~A}$ review of several empirical researches by the World Bank reveals that several studies including Muller, ${ }^{60}$ Standard and Poor, ${ }^{61}$ and Bain, ${ }^{62}$ all disclose an overestimation of traffic volumes. ${ }^{63}$ Bain concludes that one of the reasons for the overestimation appears to be optimism bias by the bidders. ${ }^{64}$

A number of project failures, bankruptcies, renegotiations and government bailouts have arisen due to mismanagement of traffic risk. ${ }^{65}$ This explains why many investors in toll roads are unwilling to assume traffic risks and are happier to transfer them to government or otherwise employ aggressive mitigation strategies ${ }^{66}$ or charge excessive premiums to assume the risk. ${ }^{67}$ Due to this, it is important that parties to toll road PPP projects are very proactive in identifying, understanding, allocating, pricing and mitigation of traffic risks. Also, a key component of traffic risks is the road users' willingness to pay. Certain factors affect road users' willingness to pay including the possibility of time savings,

\footnotetext{
${ }^{59}$ Matt Bull etal 'Toll-Road PPPs: Identifying, Mitigating and Managing Traffic Risk, PPIAF

${ }^{60}$ Muller Robert, H. 'Examining Toll Road Feasibility Studies, Public Works Financing, (1996)

${ }^{61}$ Standard \& Poor London 2005

62 Bain Robert etal, "Traffic Forecasting Risk Update 2005, Through Ramp Up and Beyond'

63 Bain Robert etal, "Traffic Forecasting Risk Update 2005, Through Ramp Up and Beyond' ibid.

${ }^{64}$ Bain, Robert 'Error and Optimism Bias in Toll Road Traffic Forecast' Transportation 36.5 (2009) 469-482

65 World bank 'Traffic Risk in Highway PPPs, Part 1, Traffic Forecasting- It is Ok to be Wrong, Just Try to be Less Wrong' Found at: https://blogs.worldbank.org/ppps/traffic-riskhighway-ppps-part-i-traffic-forecasting-it-s-ok-be-wrongjust-try-be-less-wrong (Last accessed June 2, 2020).
}

vehicle operating costs, comfort, safety, convenience, and reliability. ${ }^{68}$ All these should be taken into consideration when carrying out traffic studies.

In a toll road PPP project where concession contracts are preferred to availability contracts, the most common strategy used to mitigate traffic risk is to either allow the term of the concession or the revenue accruable to the concessionaire, adjust with demand realizations. The three most common mechanisms used to achieve this are: "modification of the economic balance" of contracts; traffic guarantee contracts; and, duration adjusted contracts. ${ }^{69}$ Under the Modification of the Economic Balance of Contracts, if the Internal Rate of Return (IRR) of the project falls below a minimum threshold stipulated in the contract, then the "economic balance" of the concession is re-established. In most cases, a minimum IRR is accompanied by a maximum IRR. This ensures that the concessionaire's profits are limited if traffic is much higher than expected, with the excess creamed off by the state. Traffic Guarantee Contracts involves guaranteeing either the traffic or revenue levels in the contract. The failure to reach this minimum levels triggers compensation from the public sector. Duration Adjusted Contracts involves matching the term of the concession to predefined and verifiable target traffic or revenue levels. ${ }^{70}$

\section{LEGAL AND REGULATORY FRAMEWORK}

Whilst addressing the media on the reintroduction of toll roads, the Minister of works alluded to the fact that there is nothing under Nigerian law barring the government from introducing toll roads. It appears that S .2 (1) (2) and (3) of the Highway Act grants the Minister of Works power to erect, equip and maintain toll gates on any Federal Highway as at when required, with the approval of the President. ${ }^{71}$ The Minister may also prescribe tolls and classify categories of vehicles and fix the amount payable by the categories of vehicles. $^{72}$ The ability of a private sector investor to be able to fix or charge toll is however not explicit. Nevertheless, S.

66 The most common method of transferring traffic risk is through the use of availability payment contracting models. Some of the aggressive mitigation methods are the use of revenue guarantee instruments, discussed in greater details below.

${ }^{67}$ This generally makes the project very expensive.

68 Matt Bull etal 'Toll-Road PPPs: Identifying, Mitigating and Managing Traffic Risk, PPIAF supra.

69 Transport Research Centre (TRANSYT) 'Evaluation of Demand Risk Mitigation in PPP Projects' (2007), pg.8

70 This approach was first applied in 1990 in the concession of the Second Severn Crossing in the United Kingdom. See:

Foice D. (1998) 'Second Severn Crossing ', Proceedings of the Seminar PPPRisk Management for Big Transport Projects, Ministerio de Fomento Spain.

${ }^{71}$ S.2(1) Federal Highways Act, Cap F13

${ }^{72}$ S.2 (1) and (2) of the Highways Act Cap F13 
2(4) of the Act grants powers to the Minister to delegate these powers to an officer, agent or person. This implies that such powers which are granted to the Minister under the Highways Act may be delegated to the private sector. In summary, this might provide sufficient basis under the existing laws for the government to enter PPP contracts where the parties to the contract are able to fix tolls.

Nevertheless, there is still a need for some form of legal reform that explicitly permits private sector tolling and other forms of PPPs. There are currently two relevant road sector bills before the National Assembly, The Federal Roads Authority Bill and the Road Fund Bill. Of the two, the Federal Roads Authority Bill is particularly important regarding the legal framework for private sector participation in road sector PPPs. It would certainly provide more certainty and provide potential private sector investors with more comfort. It is to be noted that the Federal Roads Maintenance Agency (FERMA) Act provides that "all monies collected from toll gates" are to be paid to FERMA to fund its activities. This provision is very wide and does not appear to make a distinction between toll roads that are operated by the private sector and those operated by the government. The likely conflict between the provisions of this law and whatever PPP arrangements the government is desirous of entering into ought to be reconciled.

Regulation of toll roads would likely take two forms. The first is economic regulation, which involves the fixing of toll charges on particular routes and the other is technical regulation which involves determining how the toll roads should be operated. There is no economic regulator for toll roads presently and so tariffs or tolls fees would be regulated through the contract. The problem with this is that there is no requirement under extant laws for formal consultations with the user public before the contracting parties fix toll fees. There is also no requirement for the agreed tolls to be published. Also negotiating toll fees with the private sector concessionaires under long term contracts is not very straightforward since tolls are unlikely to be static over the long-term and tolls are likely to escalate in accordance with certain economic realities, like inflation. It is important to ensure that it is not detrimental to the citizens as this was one of the major problems with the Lekki toll road project.

Technical regulation is even more problematic. Under the present institutional arrangement, the responsibility for technical regulation would appear to be with the Ministry of Works. However, the ICRC Act also allows the ICRC to monitor and enforce PPP contracts, therefore permitting the ICRC also participate in the monitoring and regulation of potential toll road PPP projects. In practice the National Assembly under its different oversight committees have also

73 This Day Newspaper Online 'The Return of Highway Tolls' Supra, Note 33 been known to join in the monitoring process. This potentially leads to multiple government agencies regulating the same project. This is certainly one of the areas where there needs to be better clarity and streamlining of responsibilities of the different government agencies.

\section{CONCLUSIONS AND RECOMMENDATIONS}

This paper considered the policy and legal implications of the recent pronouncement by the Minister of Works on the reintroduction of toll roads into the country. The following are the conclusions and recommendations reached after a thorough analysis :

Firstly, the Minister's decison to adopt tolling along the highways is going to be helpful in raising money that can be deployed towards the maintenance of the country's highways but it will not be far reaching or sustainable. This much was admitted by the Minister who pointed out that the revenues accruing from tolling will be insufficient to meet the entire cost of maintainace or replacement cost of the roads. ${ }^{73}$ It is also clear that Nigeria's required financing for the road sector cannot be met through normal budgetary provisions, therefore alternative sources of financing through PPPs ought to be explored. To this end, the paper recommends that it is imperative that the country seeks more sustainable funding options by making the projects attractive to private sector investors..

Secondly, in identifying toll road projects to be delivered through PPPs, only those that are economically-feasible and suitable should be considered. However, it is a fact that a number of the projects might not be completely viable on their own without government support in the form of revenue subsidies and viability gap funding. In these cases, clear and objective business cases should be presented prior to the adoption of the projects as PPPs. The overriding consideration for the government is ensuring that its citizens continue to enjoy quality infrastructure and the private sector achieves reasonable returns for their investment.

Thirdly, the government should create conditions that attract established and reputable private firms to invest in toll roads through transparent and predictable procedures, robust project preparation and other measures to stimulate investor appetite. This is also in accordance with Federal Government's National Policy on PPP. ${ }^{74}$ For instance, the reason why the Lagos-Ibadan toll road concession failed was due to a very opaque procurement process that did not lead to the emergence of a sufficient number of credible bidders for the project.

${ }^{74}$ Infrastructure Concession Regulatory Commission, National Policy on Public Private Partnerships (PPP), The Presidency, Abuja Nigeria 
Fourthly, it is advised that government should introduce mandatory public consultation prior to tolling of any road in Nigeria to provide users with critical information in advance. This is because tolls are very sensitive, and it is important that the user public is properly carried along. The Lekki toll road concession is a good case where the road users basically refused to pay for the use of the toll road. One of the principal reasons for the collapse of that PPP project was that the government and the private sector concessionaire failed to adequately consult with the road users before fixing the operational terms of the project.

Finally, it is advised that the government should speedily implement institutional reforms by ensuring the passage of the pending road sector bills before the National Assembly as this will help in the development of PPPs. There is also the need for the country to develop a tolling policy that communicates the policy of the government regarding tolling. A tolling policy helps to reduce the uncertainty surrounding key inputs to the traffic and revenue forecasts. There has been a draft tolling policy in place since 2015 , which may be updated and reintroduced. This will reinforce transparency, predictability and uniformity in highway toll collection.

\section{TABLE OF LEGISLATION}

\section{Statutes}

Federal Roads Maintenance Agency (Establishment, etc.) Act 2002

Federal Roads Maintenance Agency (Amendment) Act No. 18, 2007

Petroleum (Special) Trust Fund Act, No.25 of 1994

Lagos State Roads (private Sector Participation) Authority Law 2007

Lagos State Public Private Partnership Law 2011

\section{Policies}

Federal Ministry of Transport, Draft Federal Road Toll Policy Infrastructure Concession Regulatory Commission, National PPP Policy on Public Private Partnership (PPP), The Presidency, Nigeria

\section{Executive Orders}

Executive Order No.007 of 2019

\section{BIBLIOGRAPHY}

Plans

1. National Planning Commission, National Integrated Infrastructure Master Plan (NIIMP)

2. Federal Ministry of National Planning, Fourth National Development Plan, 1981-1985, Federal Ministry of Planning, Lagos, Nigeria, 1981

3. Federal Ministry of National Planning, National Rolling Plan 1991 - 1993 Vol. 1, Lagos, Federal Ministry of Planning and Budget.

\section{Books}

1. Nwangwu George, Public Private Partnerships in Nigeria: Managing Risks and Identifying Opportunities, Palgrave Macmillan UK. 2016

2. Matt Bull etal 'Toll-Road PPPs: Identifying, Mitigating and Managing Traffic Risk, PPIAF

3. Muller Robert, H. 'Examining Toll Road Feasibility Studies, Public Works Financing, (1996)

4. Transport Research Centre (TRANSYT) 'Evaluation of Demand Risk Mitigation in PPP Projects' (2007),

\section{Seminar Papers}

1. D. Foice (1998) 'Second Severn Crossing ', Proceedings of the Seminar PPPRisk Management for Big Transport Projects, Ministerio de Fomento Spain.

\section{Websites}

2. Africa Infrastructure Country Diagnostic Report 'Nigeria's Infrastructure: A Continental Perspective' February 2011 Found online at: https://ppiaf.org/documents/3154/download (last accessed on June 2, 2020)

3. Dan Agbase, 'Return of Toll Gates? First, Fix the Roads' The Guardian Newspaper found online at: https://guardian.ng/opinion/return-of-the-toll-gatesfirst-fix-the-roads/ (last accessed on 22 ${ }^{\text {nd }}$ April 2020); This Day Newspaper (online) 'The Return of Highway Tolls'

https://www.thisdaylive.com/index.php/2019/10/06 /the-return-of-highway-tolls/ (last accessed on May $7^{\text {th }}, 2020$ )

4. Legit Newspaper 'Fix Bad Roads Before Returning Toll Gates on Highways- Labour Tells FG' https://www.legit.ng/1263793-fix-bad-roadsreturning-toll-gates-highways---labour-tells-fg.html (last accessed on May $7^{\text {th }}, 2020$ )

5. Vanguard Newspaper 'Rep Rejects Toll Road in the South East' (online)

https://www.vanguardngr.com/2019/10/rep-rejectstoll-gates-in-southeast/ (last accessed on May $7^{\text {th }}$ 2020)

6. Nwannekanma B. etal 'Why Buhari Shouldn't Rebuild Toll Gates Obasanjo Removed' Guardian Newspaper found online https://guardian.ng/news/nigeria/national/whybuhari-shouldnt-rebuild-toll-gates-obasanjoremoved/ (last accessed on $7^{\text {th }}$ of May 2020)

7. Dele Bankoko found online http://nigeriavillagesquare.com/forum/threads/obas anjo-abolishes-toll-gates-in-nigeria.792/ (Last accessed $7^{\text {th }}$ May, 2020) 
8. Madukwe Bartholomew 'Minister Explains Reintroduction of Toll Gates' Found online at https://www.vanguardngr.com/2011/11/ministerexplains-reintroduction-of-toll-gates/ (Last accessed on June 02,2020 )

9. Premium Times 'Toll Gates, Weighbridges to Return to Nigerian Roads- Minster Onolememen https://www.premiumtimesng.com/news/152968toll-gates-weigh-bridges-return-nigerian-roadsminister-onolememen.html

10. This Day Newspaper Online 'The Return of Highway Tolls' October 6, 2019. Found online at https://www.thisdaylive.com/index.php/2019/10/06 /the-return-of-highway-tolls/ (Last accessed on $16^{\text {th }}$ of April, 2020)

11. 'Companies, Roads to be Constructed Under Buhari,s Executive Order 7' Found online at https://insidebusiness.ng/65602/full-list-companiesroads-to-be-constructed-under-buharis-executiveorder-7/ (Last accessed on June 2, 2020)

12. Naira Metrics, 'Pension Fund Assets hits N9.3 trillion as investment in FGN Securities drops' Found online at: https://nairametrics.com/2019/08/10/pension-fundassets-hits-n9-3-trillion-as-investment-in-fgnsecurities-drops/ (last accessed on June 2, 2020)

13. World bank 'Traffic Risk in Highway PPPs, Part 1, Traffic Forecasting- It is Ok to be Wrong, Just Try to be Less Wrong' Found at: https://blogs.worldbank.org/ppps/traffic-riskhighway-ppps-part-i-traffic-forecasting-it-s-ok-bewrong-just-try-be-less-wrong (Last accessed June 2, 2020).

\section{Journals}

1. Ruiz-Nunez F. and Wei Zichao, 'Infrastructure Investment Demands in Emerging Markets and Developing Economies' World Bank Policy Research Paper 7414

2. Central Bank of Nigeria 'Highway Maintenance in Nigeria: Lessons from Other Countries' Research Department Occasional Papers, No.27, April 2003

3. G. Nwangwu 'The Legal Framework for PublicPrivate Partnerships (PPPs) In Nigeria: Untangling the Complex Web', European Procurement and Public Private Partnership Law Review, Volume 7 (2012), Issue 4, Pg. 268-277
4. E. Dannin 'Crumbling infrastructure, Crumbling Democracy: Infrastructure Privatization Contracts and Their Effects on State and Local Governance', (2011) 6 North western Journal of Law \& Social Policy

5. Iossa, E. and Martimort, D. [2008], 'The Simple Micro-Economics of Public-Private Partnerships', Working Paper, (online) at http://papers.ssrn.com/paper.taf?abstract id=13182 67 [last accessed on May 15, 2019]

6. Tagged "Occupy Lekki" See Sahara Reporters 'Occupy Lekki: Lagos Protests Against Lekki Toll Gate' (online) Available at: http//www.saharareporters.com/newspage/occupy-lekki-lagos-protests-against-lekki-tollgate (last accessed August 12, 2013)

7. Dannin, E. 'Crumbling infrastructure, Crumbling Democracy: Infrastructure Privatization Contracts and Their Effects on State and Local Governance', (2011) 6 North western Journal of Law \& Social Policy Pg.47

\section{Newspaper Articles}

1. Okoruwa S. and Olabulo O. '1 Killed, Many injured in Lekki Tollgate Protests' Nigerian Tribune Newspaper, May 28, 2019

2. Compas Newspaper 'PDP Calls for Fashola's Impeachment Over Lekki Toll Plaza Nigeria Compass Newspaper, December 16, 2011

3. Benson D. 'Lekki/Epe Expressway Toll Plaza: Lagos Govt Violated our Fundamental Right to Protest - Adegboruwa' Vanguard Newspaper 22 ${ }^{\text {nd }}$ December 2011

Reports

1. D. Hall (2008) Public-Private Partnerships (PPPs) Summary Paper, A Report Commissioned by the European Federation of Public Service Unions (EPSU)

\section{Technical Notes}

1. Querioz C. etal 'Mechanism for Financing Roads: A Review of International Best Practice' December 2016' Inter-American Development Bank. Technical Note Number IDB-TN-1102 pg.5 